Notes and Comments

\title{
Exogenous application of organic acids in maize seedlings under salt stress
}

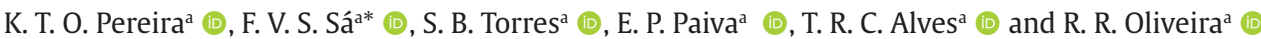 \\ aUniversidade Federal Rural do Semi-Árido - UFERSA, Centro de Ciências Agrárias, Campus Mossoró, Mossoró, RN, Brasil
}

The semi-arid region is characterized by higher evapotranspiration than precipitation, which intensifies the use of saline water in irrigation (Minhas et al., 2020). Salt stress causes restrictions of osmotic and ionic order, and the osmotic component is responsible for limiting water absorption, causing reductions in the relative water content, turgor pressure and cell water potential (Wan et al., 2017). The ionic component causes toxicity by specific ions, such as $\mathrm{Na}^{+}$, leading to restrictions on nutrient absorption, protein synthesis, lipid metabolism and photosynthesis (Volkov and Beilby, 2017).

Maize (Zea mays L.) is sensitive to salt stress, with salinity threshold of $1.1 \mathrm{dS} \mathrm{m}^{-1}$ in irrigation water and $1.7 \mathrm{dS} \mathrm{m}^{-1}$ in soil saturation extract (Ayers and Westcot, 1985). However, there are differences in tolerance between genotypes, between salinity levels and types of salts present in water or soil (Zahra et al., 2018). Studies indicate that the use of attenuating substances improves the response of plants to salt stress, such as ascorbic acid (Alhasnawi et al., 2016), salicylic acid (Batista et al., 2019), and gibberellic acid (Sá et al., 2020). These acids perform functions of chemical messengers, responsible for tissue formation and growth, intercellular communication mediators, assisting in the translation of stress signal and homeostasis (Volkov and Beilby, 2017).

Therefore, the objective of this study was to evaluate the exogenous application of organic acids in maize genotypes subjected to salt stress. For this, an experiment was conducted in a greenhouse of the Federal Rural University of the Semi-Arid Region (UFERSA), in Mossoró, RN, Brazil (5'11' S, 37²0' W, and 18 m altitude). The climate of the region is semi-arid and, during the experiment, the maximum and minimum temperatures were $46{ }^{\circ} \mathrm{C}$ and $24{ }^{\circ} \mathrm{C}$, respectively, with maximum relative humidity of $82 \%$ and minimum relative humidity of $22 \%$.

The maize genotypes BRS 2022 and Potiguar were subjected to low-salinity water $\left(0.5 \mathrm{dS} \mathrm{m}^{-1}\right)$ (control), high-salinity water $\left(7.0 \mathrm{dS} \mathrm{m}^{-1}\right)$ (salt stress), salt stress plus gibberellic acid in post-emergence $(50 \mu \mathrm{mol})$, salt stress plus salicylic acid in post-emergence ( $50 \mu \mathrm{mol})$ and salt stress plus ascorbic acid in post-emergence ( $50 \mu \mathrm{mol})$.

The seeds were sown in polyethylene trays of 200 cells, filled with inert substrate based on coconut fiber. Daily irrigation was performed by the floating-type seedling irrigation system. High-salinity water was obtained by the addition of $\mathrm{NaCl}, \mathrm{CaCl}_{2} .2\left(\mathrm{H}_{2} \mathrm{O}\right)$ and $\mathrm{MgCl}_{2} \cdot 6\left(\mathrm{H}_{2} \mathrm{O}\right)$ salts in the proportion of $7: 2: 1$, respectively, and the low-salinity water (local supply) was obtained according to Sá et al. (2020).

On the fourth day after sowing, the exogenous application of organic acids (through the leaves) was performed with a $50 \mathrm{ml}$ sprayer bottle, using $30 \mathrm{~mL}$ for 200 plants. On the seventh day after sowing, the following parameters were determined: seedling length (SL), expressed in $\mathrm{cm}$ seedling ${ }^{-1}$, seedling dry mass (DM), expressed in $\mathrm{mg}$ seedling ${ }^{-1}$ and root/shoot dry mass ratio (Root/Shoot).

The experimental design was completely randomized, in a $2 \times 5$ factorial scheme, with four replicates of 50 seeds. The data obtained were subjected to analysis of variance, $F$ test. In cases of significance, Dunnett's test was performed to compare the exogenous application of organic acids and Tukey test was applied to compare maize genotypes, with $5 \%$ significance level.

The interaction was significant $(p<0.05)$ between the exogenous application of organic acids and maize genotypes for the length, dry mass and root/shoot ratio of maize seedlings (Figures 1 and 2).

For the genotypes BRS 2022 and Potiguar, seedling length was reduced by 14.2 and $20.1 \%$ as water salinity increased from $0.5 \mathrm{dS} \mathrm{m}^{-1}$ to $7.0 \mathrm{dS} \mathrm{m}^{-1}$, respectively (Figure $1 \mathrm{~A}$ ). In BRS 2022 maize under salt stress, the exogenous application of ascorbic acid resulted in seedling length equal to that of the control treatment (Figure $1 \mathrm{~A}$ ). The genotype BRS 2022 obtained a higher seedling length than Potiguar in all treatments, under salt stress except application of gibberellic acid (Figure 1A).

The dry mass of the maize genotypes BRS 2022 and Potiguar was reduced by 14.1 and $27.6 \%$ under high salinity $\left(7.0 \mathrm{dS} \mathrm{m}^{-1}\right)$ compared to low salinity $\left(0.5 \mathrm{dS} \mathrm{m}^{-1}\right)$, respectively (Figure $1 \mathrm{~B}$ ). The exogenous application of organic acids did not influence the dry mass accumulation of maize (Figure 1B). The dry mass accumulation of the genotype BRS 2022 was 29.8 and $54.0 \%$ higher than those of Potiguar, under the conditions of low $\left(0.5 \mathrm{dS} \mathrm{m}^{-1}\right)$ and high $\left(7.0 \mathrm{dS} \mathrm{m}^{-1}\right)$ salinity, respectively (Figure $1 \mathrm{~B}$ ).

Salt stress reduced the root/shoot ratio of the maize genotypes BRS 2022 and Potiguar compared to the control (Figures 2A-D). The Root/Shoot of BRS 2022, under salt

*e-mail: vanies_agronomia@hotmail.com

Received: April 6, 2021 - Accepted: July 8, 2021 
A

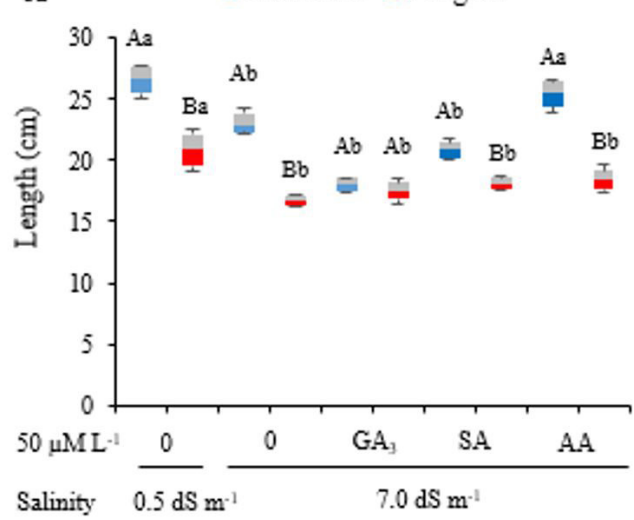

B

- BRS 2022 = Potiguar

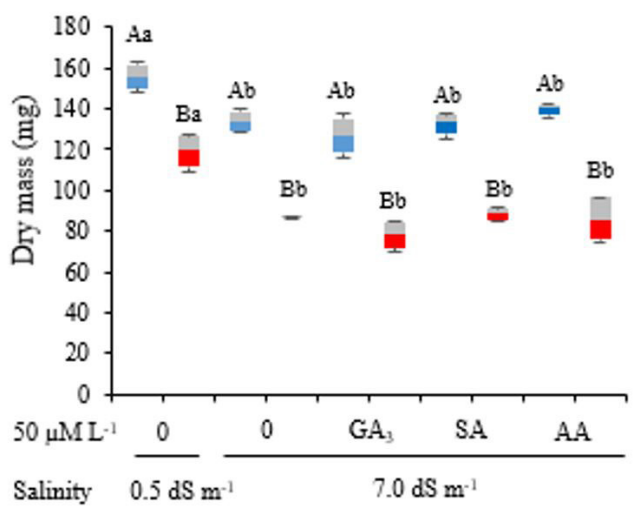

Figure 1. Length (A) and dry mass (B) of maize seedlings under salt stress and application of organic acids $\left(\mathrm{GA}_{3}=\right.$ gibberellic acid, $\mathrm{SA}=$ salicylic acid and $\mathrm{AA}=$ ascorbic acid). Lowercase letters compare application of organic acids and uppercase letters compare genotypes .

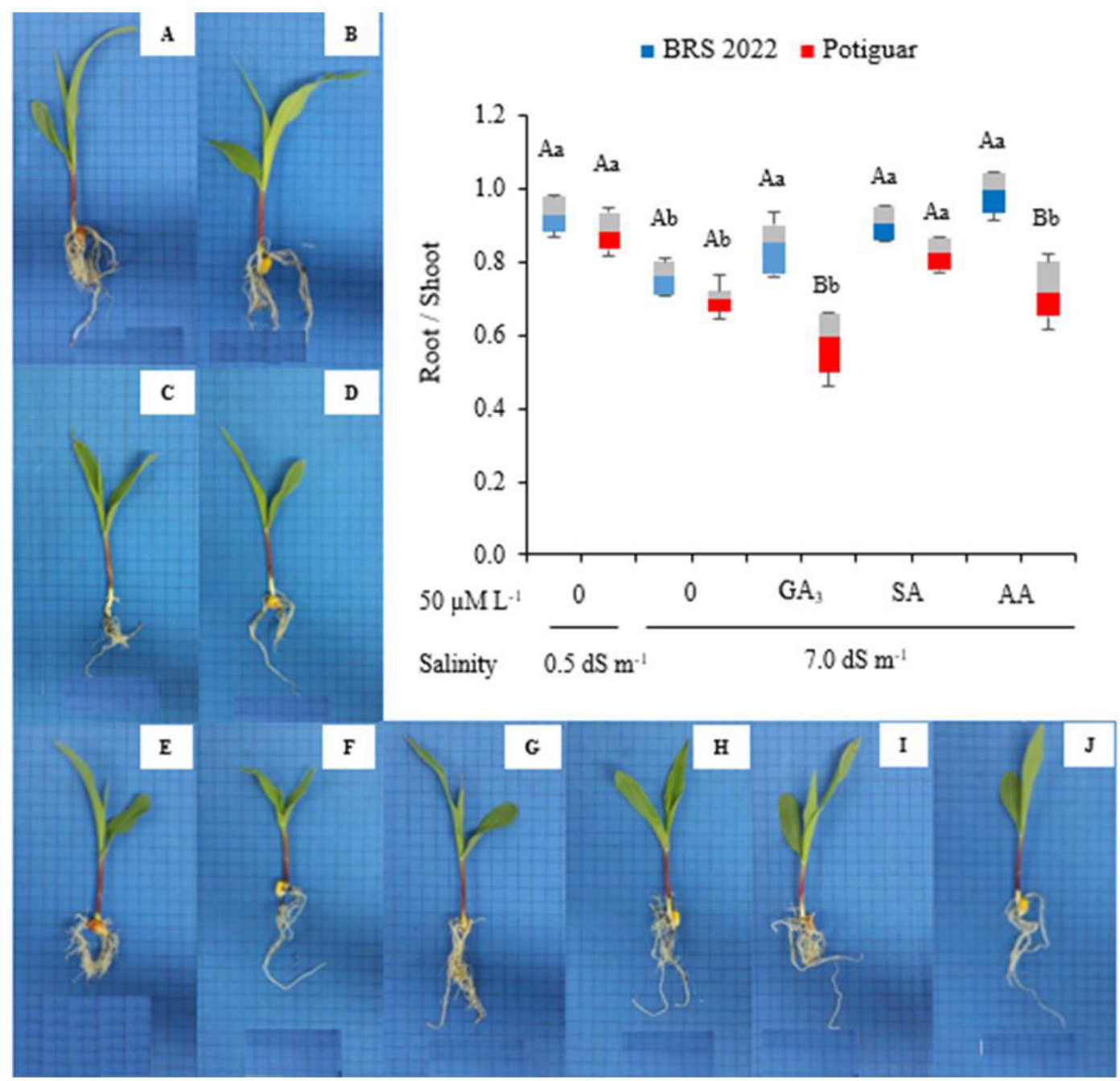

Figure 2. Root/shoot ratio of maize seedlings under salt stress and application of organic acids $\left(\mathrm{GA}_{3}=\right.$ gibberellic acid, $\mathrm{SA}=$ salicylic acid and AA = ascorbic acid). BRS 2022 (A, C, E, G and I), Potiguar (B, D, F, H and J). Control (A and B), salt stress (C and D), GA 3 (E and $\mathrm{F}), \mathrm{SA}(\mathrm{G}$ and $\mathrm{H})$ and $\mathrm{AA}$ ( $\mathrm{I}$ and $\mathrm{J})$. Lowercase letters compare application of organic acids and uppercase letters compare genotypes. 
stress with application of $50 \mu \mathrm{mol}$ of $\mathrm{GA}_{3}$, SA and AA in post-emergence, was similar to that of the control (Figures 2A, E, G and I). The Root/Shoot of Potiguar, under salt stress with application of $50 \mu \mathrm{mol}$ of SA in post-emergence, was equivalent to that of the control (Figures $2 \mathrm{~B}$ and $\mathrm{H}$ ), and with the application of $50 \mu \mathrm{mol}$ of $\mathrm{GA}_{3}$ and $\mathrm{AA}$ in post-emergence the Root/Shoot was lower than that of the control (Figures 2B, F and J). The Root/ Shoot of BRS 2022 maize under salt stress with application of $50 \mu \mathrm{mol}$ of $\mathrm{GA}_{3}$ and $\mathrm{AA}$ in post-emergence was higher than that of Potiguar (Figures 2E, F, I and J).

Salt stress $\left(7.0 \mathrm{dS} \mathrm{m}^{-1}\right)$ reduced the growth and biomass accumulation of maize seedlings (Figure 2C and 2D). Under this condition, the increase in osmotic pressure in the cultivation medium limits plant growth, as verified by Zahra et al. (2018) in two maize varieties subjected to $\mathrm{NaCl}$-induced salt stress. The water deficit caused by excess salts hampered the absorption of water by the roots, and consequently, the processes of cell division and elongation were affected (Sá et al., 2020). Excess of salts also causes nutritional imbalance and toxicity by specific ions ( $\mathrm{Na}^{+}$and $\mathrm{Cl}^{-}$) (Volkov and Beilby, 2017). Salt stress compromises the mobilization of seed reserves and, consequently, reductions occur in respiratory activity, water absorption and carbon absorption and fixation (Batista et al., 2019; Silva et al., 2019).

Ascorbic acid promoted greater seedling length. This antioxidant agent prevented the oxidation of membranes and delayed cell death, increasing rice tolerance to salt stress (Alhasnawi et al., 2016).

Ascorbic, gibberellic and salicylic acids improved Root/Shoot in BRS 2022 maize, balancing the distribution of reserves for shoot and root growth. In Potiguar, this distribution for the growth of the respective parts was improved with the use of SA in post-emergence. Gibberellic and salicylic acids also perform oxidizing activity, besides acting as growth regulators and stress signaling molecules, improving homeostasis (Batista et al., 2019; Sá et al., 2020).

The highest losses of growth and biomass accumulation occurred in the Potiguar genotype, which is more sensitive to salinity than BRS 2022. Exogenous application of organic acids in post-emergence was less effective for the Potiguar genotype, except for the application of salicylic acid.

\section{References}

ALHASNAWI, A.N., RADZIAH, C.M.Z., KADHIMI, A.A., ISAHAK, A., MOHAMAD, A. and YUSOFF, W.M.W., 2016. Enhancement of antioxidant enzymes activities in rice callus by ascorbic acid under salinity stress. Biologia Plantarum, vol. 60, no. 4, pp. 783787. http://dx.doi.org/10.1007/s10535-016-0603-9.

AYERS, R.S. and WESTCOT, D.W., 1985. Water quality for agriculture. Rome: FAO, $174 \mathrm{p}$.

BATISTA, V.C.V., PEREIRA, I.M.C., PAULA-MARINHO, S.O., CANUTO, K.M., PEREIRA, R.C.A., RODRIGUES, T.H.S., DALOSO, D.M., GOMESFILHO, E. and CARVALHO, H.H., 2019. Salicylic acid modulates primary and volatile metabolites to alleviate salt stress-induced photosynthesis impairment on medicinal plant Egletes viscosa. Environmental and Experimental Botany, vol. 167, pp. 103870. http://dx.doi.org/10.1016/j.envexpbot.2019.103870.

MINHAS, P.S., RAMOS, T.B., BEN-GAL, A. and PEREIRA, L.S., 2020. Coping with salinity in irrigated agriculture: crop evapotranspiration and water management issues. Agricultural Water Management, vol. 227, pp. 105832. http://dx.doi. org/10.1016/j.agwat.2019.105832.

SÁ, F.V.S., BRITO, M.E.B., SILVA, L.A., MOREIRA, R.C.L., PAIVA, E.P. and SOUTO, L.S., 2020. Exogenous application of phytohormones mitigates the effect of salt stress on Carica papaya plants. Revista Brasileira de Engenharia Agrícola e Ambiental, vol. 24, no. 3, pp. 170-175. http://dx.doi.org/10.1590/1807-1929/agriambi. v24n3p170-175.

SILVA, H.A., OLIVEIRA, D.F.A., AVELINO, A.P., MACÊDO, C.E.C., BARROSGALVÃO, T. and VOIGT, E.L., 2019. Salt stress differentially regulates mobilisation of carbon and nitrogen reserves during seedling establishment of Pityrocarpa moniliformis. Plant Biology, vol. 21, no. 6, pp. 1110-1118. http://dx.doi.org/10.1111/ plb.13017. PMid:31173441.

VOLKOV, V. and BEILBY, M.J., 2017. Salinity tolerance in plants: mechanisms and regulation of ion transport. Frontiers in Plant Science, vol. 8, no. 10, pp. 1795. http://dx.doi.org/10.3389/ fpls.2017.01795. PMid:29114255.

WAN, Q., HONGBO, S., ZHAOLONG, X., JIA, L., DAYONG, Z. and YIHONG, H., 2017. Salinity tolerance mechanism of osmotin and osmotin-like proteins: a promising candidate for enhancing plant salt tolerance. Current Genomics, vol. 18, no. 6, pp. 553556. http://dx.doi.org/10.2174/138920291866617070515304 5. PMid:29204083.

ZAHRA, N., MAHMOOD, S. and RAZA, Z.A., 2018. Salinity stress on various physiological and biochemical attributes of two distinct maize (Zea mays L.) genotypes. Journal of Plant Nutrition, vol. 41, no. 11, pp. 1368-1380. http://dx.doi.org/10.1080/0190416 7.2018.1452939. 